\title{
A RCA Analysis of China's Competitive Advantage to Export Textile and Apparel to Australia
}

\author{
Chunying Cui \\ School of Economics \&Management \\ Wenhua College \\ Wuhan, China \\ dannycui@163.com
}

\author{
Shaoshao Chen \\ School of Economics \&Management \\ Wenhua College \\ Wuhan, China
}

\begin{abstract}
The textile and apparel (TA) trade between China and Australia was investigated by calculating trade indices, based on an overview of status quo. The paper used Revealed Comparative Advantage (RCA) method to analyze TA trade advantage between China and Australia. Then, factors that affect China's TA exports to Australia were analyzed in terms of demand effect, structural effect, and competitiveness effect. The results show that the concentration of Australia's TA imports from China was high, due to the low competitiveness of its TA goods. Thus Australia's demand matches China's exports well. An empirical analysis suggests that signing a China-Australia Free Trade Agreement (FTA) will increase China's TA exports to Australia, boost China's domestic production and promote employment.
\end{abstract}

Keywords-apparel trade; Free Trade Agreement; trade relationship

\section{INTRODUCTION}

The China-Australia Free Trade Agreement (FTA) is a result of a series of activities such as research and negotiations based on theories about regional economic integration. It aims to rationalize the allocation of factors between Australia and China, remove trade barriers and thereby achieve free flow of goods and services between the two countries. This agreement covers a broader range of issues, has more comprehensive content and calls for an overall high degree of trade and investment liberalization.

TABLE I. SCHEDULE OF THE CHINA-AUSTRALIA FTA NEGOTIATIONS

\begin{tabular}{|c|c|}
\hline Date & Chinese exports to Australia \\
\hline Apr, 2005 & Officially start the negotiations \\
\hline Nov, 2005 & Complete the first negotiation phase \\
\hline Aug, 2009 & Restart the FTA negotiations \\
\hline Feb, 2010 & $\begin{array}{c}\text { The 14th round of the FTA negotiations in } \\
\text { Canberra }\end{array}$ \\
\hline June, 2013 & $\begin{array}{l}\text { The 19th round of the FTA negotiations in } \\
\text { Beijing }\end{array}$ \\
\hline Nov, 2014 & $\begin{array}{c}\text { Announce a substantive end to the FTA } \\
\text { negotiations }\end{array}$ \\
\hline June, 2015 & Officially sign the FTA \\
\hline
\end{tabular}

TABLE II. A COMPARISON BETWEEN AUSTRALIA AND CHINA IN TERMS OF TRADE IN ZERO-TARIFF GOODS

\begin{tabular}{|c|c|c|}
\hline Country & $\begin{array}{c}\text { Proportion of } \\
\text { tax items }\end{array}$ & $\begin{array}{c}\text { Proportion of volume of } \\
\text { trade }\end{array}$ \\
\hline Australia & $100 \%$ & $100 \%$ \\
\hline China & $96.70 \%$ & $97 \%$ \\
\hline
\end{tabular}

In addition, as the TA industry is a key traditional industry in China, variation in TA exports has an important influence on China's foreign trade and economic development.

Therefore, an analysis of competitiveness of China's TA exports under the framework of a China-Australia FTA is of great significance.

\section{LITERATURE REVIEW}

Scholars have conducted extensive studies on the signing of a China-Australia FTA. Most of the studies have focused on the agricultural trade between the two countries based on a China-Australia FTA, but only a few have looked at the TA trade.

\section{A. As for agricultural products}

Yang Jun, Huang Jikun and Qiu Huanguang (2005) have used the GTAP model to investigate how the establishment of a China-Australia free trade area would influence the two countries' national income, agriculture, and industry. ${ }^{[1]}$ It was found that after establishment of a China-Australia free trade area, Australia's national income was expected to increase $0.2 \%$, while China's national income would grow only $0.1 \%$. The increase in Australia's national income would come from agriculture and industry, with the former contributing two times more than the latter. In contrast, the national income increase in China would be solely attributed to its industrial growth.

The study by He Haojun, Zhu Shujin and Xiao Hao (2009) used a computable general equilibrium (CGE) approach and it revealed that establishing a China-Australia free trade area could result in declines in the output of most Chinese agricultural products and gap in growth rates of agricultural imports and exports between the two countries, which will further widen China's trade deficit in agricultural goods with Australia. ${ }^{[2]}$ 
Hao Ruilin (2010) has analyzed the wool trade between China and Australia, factors influencing their wool trade, and the potential impact of a China-Australia free trade area on their wool trade by calculating trade indices and using a constant market share model, an econometric regression model and a static analysis model. ${ }^{[3]}$ The study found that the establishment of a China-Australia free trade area would have a great impact on China's wool industry by limiting the room for growth of this industry and reducing the income of wool growers.

Guo Ting (2013) has investigated the potential impact of a China-Australia free trade area on China's imports of dairy products using the gravity model of trade and a GTAP model. ${ }^{[4]}$ The results showed that establishing a China-Australia free trade area would create huge potential and much room for growth of wool trade between China and Australia, but the huge price advantage of Australian dairy products would pose a great challenge to the survival and development of Chinese dairy farms.

\section{B. As for TA trade}

Liu Chenyang (2006) argued that establishing a ChinaAustralia free trade area could promote bilateral trade and investment and help expand their political and economic cooperation, but it would also have a great impact on China's agriculture. ${ }^{[5]}$ China would need to take specific measures for industrial restructuring. Based on theories about regional economic integration, Qiu Xiaodan (2008) has discussed the complementarity and competitive between the trade structures of China and Australia and performed an in-depth analysis of staple commodities. ${ }^{[6]}$ The research concluded that if a free trade area was established, the two countries would be able to exploit their comparative advantages and factor endowments to expand their intra-industry trade and accelerate the upgrading of their industrial structures.

Jia Xin (2014) and Li Jieqiong (2015) have studied the impact of Australia cutting tariffs on textile imports after a China-Australia free trade area was established. ${ }^{[7]}{ }^{[8]}$ They found that establishing a China-Australia free trade area would have a significant impact on the textile trade between the two countries and if the tariffs were eliminated, China's textile exports to Australia were forecast to increase $26 \%$.

\section{Overview of TeXtile AND ApPaRel Trade BETWeEN CHINA AND AUSTRALIA}

\section{A. Status Quo of China's Textile and Apparel Industry}

As a traditional and competitive industry as well as an important sector of China's economy, the TA industry plays an important role in China's economic development. China has seen rapid development of the TA industry since its entry into WTO. However, some problems have arisen. First, the growth rate of TA exports has decreased from $23.71 \%$ in 2010 to $5.1 \%$ in 2014. The proportion of TA exports in the country's total exports has also declined year by year. Second, as the TA industry is labor intensive, a number of countries have introduced relevant protection policies, which can easily trigger a trade war. Furthermore, Chinese exports of textiles and apparel are likely to be contained by the buyers as the export markets are largely concentrated in developed Western countries.

TABLE III. CHINA's TA EXPORTS AND TOTAL EXPORTS BETWEEN 2004 AND 2014 (IN MILLION USD)

\begin{tabular}{|c|c|c|}
\hline Year & Textile and apparel exports & Total exports \\
\hline 2014 & 287584 & $2,342,293$ \\
\hline 2013 & 273,959 & $2,209,004$ \\
\hline 2012 & 246,045 & $2,048,714$ \\
\hline 2011 & 240,539 & $1,898,381$ \\
\hline 2010 & 199,533 & $1,577,754$ \\
\hline 2009 & 161,409 & $1,201,612$ \\
\hline 2008 & 179,734 & $1,430,693$ \\
\hline 2007 & 165,802 & $1,220,456$ \\
\hline 2006 & 138,094 & 968,978 \\
\hline 2005 & 107,661 & 761,953 \\
\hline 2004 & 88,767 & 593,326 \\
\hline
\end{tabular}

${ }^{\text {a. }}$ Data source: China Statistical Yearbook by National Bureau of Statistics of the People's Republic of

Table 3-1 shows that, China's TA exports increased every year from 2004 to 2014; except for a small decline in 2009 (the total exports also fell that year due to the financial crisis). The TA exports had more than tripled over the 11 years from 2004 to 2014 .

\section{B. Status Quo of China's Textile and Apparel Trade with Australia}

China is currently Australia's largest trade partner, source of imports, and export market. In comparison, Australia is China's eighth-biggest trade partner, seventh-biggest source of imports, and ninth-biggest export market. In 2014, China's exports to Australia reached 46.771 billion USD; a $3.12 \%$ increase compared to 2013, and accounted for $20.51 \%$ Australia's total imports, up 1\% from 2013. In terms of TA trade, China's exports to Australia were about 5.47 billion USD in 2014 , representing $11.49 \%$ of its total exports to Australia.

\section{TABLE IV. CHINA's TA TRADE WITH AUSTRALIA BETWEEN 2006 AND} 2014 (IN MILLION USD)

\begin{tabular}{|c|c|c|}
\hline Year & Chinese exports to Australia & Australian imports \\
\hline 2014 & 5,473 & 8,836 \\
\hline 2013 & 5,357 & 8,494 \\
\hline 2012 & 5,333 & 8,273 \\
\hline 2011 & 5,246 & 8,029 \\
\hline 2010 & 4,542 & 6,866 \\
\hline 2009 & 3,640 & 5,673 \\
\hline 2008 & 3,873 & 6,165 \\
\hline 2007 & 3,417 & 5,578 \\
\hline 2006 & 2,984 & 4,919 \\
\hline
\end{tabular}

b. Data sources: China Statistical Yearbook and Country Report by the Ministry of Commerce of the People's Republic of China. 
Table 2-2 shows that China's TA exports to Australia increased every year between 2006 and 2014, and made up more than $60 \%$ of Australia's TA imports, demonstrating that China's TA exports to Australia held an important position in the trade relations between the two countries.

\section{ANALYSIS OF INDICES OF THE TA TRADE RELATIONSHIP BETWEEN CHINA AND AUSTRALIA}

\section{A. Revealed comparative advantage (RCA)}

Revealed comparative advantage (RCA) is an index designed by Balassa in 1965 to measure comparative advantage from the perspective of commodity exports, and it is widely used by international organizations such as the World Bank. RCA is given by Eq. 1 below:

$$
R C A_{i j}=\frac{x_{i j} / \sum_{j} x_{i j}}{\sum_{j} x_{i j} / \sum_{j} \sum_{j}^{j} x_{i j}}
$$

Where $\mathrm{RCA}_{\mathrm{ij}}$ is the revealed comparative advantage of country $i$ in commodity $j ; X_{\mathrm{ij}}$ is the exports of commodity $j$ from country $i ; \sum_{i} X_{i j}$ is the total exports of country $i$; $\sum_{j} X_{i j}$ is the world exports of commodity $j$, and $\sum_{j} \sum^{j} X_{\mathrm{ij}}$ is total world exports of commodities.

TABLE V. CORRELATIONS BETWEEN RCA RANGE AND COMPARATIVE ADVANTAGE

\begin{tabular}{|c|c|}
\hline RCA range & Comparative advantage \\
\hline$>2.5$ & Very high \\
\hline $1.25 \sim 2.5$ & High \\
\hline $0.8 \sim 1.25$ & Medium and unstable \\
\hline$<0.8$ & Low \\
\hline
\end{tabular}

The trade index RCA is very operable in research on comparative advantage in commodities trade. It uses price to represent comparative advantage and takes into account the export volume so that it can effectively reflect the idea of the theory of comparative advantage. Moreover, since RCA measures a country's comparative advantage relative to the world, the export data required is easily available and complete and allows effective comparison.

Assuming that $\mathrm{X}$ represents the ratio of the world's TA exports to world's total exports, the calculations for China and Australia then have the same bottom number. According to Table 3-2, China's TA exports amounted to more than $12 \%$ of its total exports, while the proportion of Australia's TA exports in its total exports was only about $2 \%$. It follows that China has a comparative advantage over Australia in TA trade.
TABLE VI. PROPORTIONS OF CHINA'S AND AUSTRALIA's TA EXPORTS IN THEIR TOTAL EXPORTS

\begin{tabular}{|c|c|c|}
\hline Year & China & Australia \\
\hline 2014 & $12.28 \%$ & $1.85 \%$ \\
\hline 2013 & $12.40 \%$ & $2.16 \%$ \\
\hline 2012 & $12.01 \%$ & $2.27 \%$ \\
\hline 2011 & $12.67 \%$ & $2.24 \%$ \\
\hline 2010 & $12.65 \%$ & $1.63 \%$ \\
\hline 2009 & $13.43 \%$ & $1.51 \%$ \\
\hline 2008 & $12.56 \%$ & $1.53 \%$ \\
\hline 2007 & $13.59 \%$ & $2.47 \%$ \\
\hline 2006 & $14.25 \%$ & $2.58 \%$ \\
\hline
\end{tabular}

\section{B. Analysis of Factors Affecting China's TA exports to Australia}

In the previous section, the TA trade relationship between China and Australia is analyzed in terms of several bilateral trade indices. This analysis can lead to a conclusion that the two countries have maintained a close relationship in TA trade. The present section focuses on analysis of factors affecting China's TA exports to Australia.

\section{1) Analysis of demand effect:}

In this subsection, Australia's total TA imports from the rest of the world represent Australia's import demand for TA goods. The demand effect of TA trade between China and Australia was studied through an analysis of the relationship between Australia's total TA imports and its TA imports from China.

There is a positive correlation between Australia's total TA imports and its TA imports from China. This suggests that China is very capable of producing and exporting TA goods to satisfy the demand in Australian market.

\section{2) Analysis of structural effect:}

The index of import concentration was used here to analyze the ability of China's TA export structure to adapt to changes in Australia's import demand, in order to measure structural effect. This index can well reflect the degree of concentration of Australia's TA imports from China. It is defined by:

$$
C_{t}=100 * \frac{X_{i t}}{X_{t}}
$$

Where $X_{i t}$ is Australia's TA imports from China during the period $t$ and $X_{t}$ is Australia's total TA imports during that period. The value of $\mathrm{Ct}$ ranges from 0 to 100; a larger value suggests a higher degree of concentration of imports from China.

So the concentration of Australia's TA imports from China was relatively high; after peaking at 66.15 in 2010 , it began to fall but remained above 60 . The high concentration implies that China's TA export structure was highly adaptable to changes in Australia's demand. 
3) Analysis of competitiveness effect:

In applied economics, the competitiveness of a specific product from a given country is normally affected by a number of factors, primarily by price and quality. In international trade theory, price competitiveness and quality competitiveness are analyzed using David Ricardo's theory of comparative advantage and Michael Porter's theory of competitive advantage, respectively. Theoretical analyses of competitiveness of a certain product from a certain country or region are largely based on calculations of various trade indices.

The TA trade between China and Australia were analyzed in terms of several indices such as revealed comparative advantage and trade competitiveness. A conclusion can be drawn from the analyses above: overall, China has a distinct advantage over Australia in their bilateral TA trade.

\section{CONCLUSIONS}

Overall, China has a comparative advantage over Australia in the TA industry and they had a close relationship in TA trade. China has recorded a long-term trade surplus in TA with Australia. As Australia's biggest source of TA imports, China has long accounted for more than $60 \%$ of Australia's TA imports. Besides, the volume of trade between them shows an upward trend.

\section{A. Factors Affecting the TA Trade between China and Australia}

Australia's imports of Chinese textiles and apparel have been primarily affected by demand effect, structural effect, and competitiveness effect. The factor analysis indicates that Chinese TA goods meet Australia's demand and enjoy a competitive advantage in Australian market.

\section{B. Impact of the Signing of a China-Australia FTA on China's TA Exports to Australia}

The impact of abolition of import tariffs on China's TA industry was analyzed using a static model. It was predicted that in the context of zero tariff, China's TA exports to Australia would increase, thus raising production and labor income in this industry. The resulting increase in labor demand will effectively promote China's employment and thus alleviate its employment pressure.

\section{ACKNOWLEDGMENT}

This work is supported by the Social Science Foundation of Hubei Provincial Department of Education (Grant: 15G191), the PHD Research Foundation of Wenhua College (Grant: 2013Y02).

\section{REFERENCES}

[1] Yang Jun, Huang Jikun, Qiu Huanguang. "On the Economic Effect of Setting Up the China-Australia Free Trade Area and Policy Suggestions ", Journal of International Trade.2005,11

[2] He Haojun, Zhu Shujin, Xiao Hao. "A CGE Analysis of the Impact of Tariff Cut on China's Agriculture After Establishment of a ChinaAustralia Free Trade Area ", Inquiry into Economic Issues.2009,11

[3] Hao Ruilin. "Study of Wool Trade between China and Australia from the Perspective of a FTA", Thesis for Master's degree, Inner Mongolia Agricultural University. 2010

[4] Fang Zhimin. "A Study of Problems with the Export Competitiveness of China's Textile Industry and Countermeasures", Shang Qing. 2014(42)

[5] Liu Chenyang. “An Investigation into China's Participation in Bilateral FTAs”, Tianjin: Nankai University Press, 2006.3

[6] Qiu Xiaodan. "A Study of the Trade Basis and Effects of Establishing a China-Australia Free Trade Area”, Thesis for Master's degree, Xiamen University. 2008.

[7] Jia Xin. "An Analysis of Chinese Textile Exports", China Business Update.2014(18)

[8] Li Jieqiong. "An investigation into Issues Regarding the International Competitiveness of China's Textile Industry ", Market Modernization. 2015(28) 